\title{
O aprendizado do não-saber na mística de Angelus Silesius* The learnig of the not-knowing in the mystique of Angelus Silesius
}

\author{
Cleide Maria de Oliveira**
}

\section{Resumo}

A linguagem apofática é um gênero discursivo estreitamente relacionado à Teologia Negativa, cuja formulação mais acabada se encontra na obra do Pseudo-Dionísio (séc. V), místico que funda uma tradição negativa que se perpetuará durante toda a Idade Média e Moderna. Na contemporaneidade diversos autores (DERRIDA, 1995 e 1997; FRANKE, 2007; PONDÉ, 2003; VEGA, 2004 e 2009 e outros) têm destacado a retomada desse gênero discursivo nas artes, na literatura e nas ciências humanas de forma geral. A linguagem apofática é, portanto, um discurso que visa à própria transcendência e se orienta para a denúncia de um vazio intrínseco à linguagem e ao mundo que dela se origina, de tal modo que o Deus que aí comparece desliza sob nossa linguagem sem se deixar prender em nossas teias discursivas. No presente texto a impossibilidade do nome de Deus torna-se metáfora para se refletir, a partir do exemplo da mística de Angelus Silesius, sobre as possibilidades de um pensamento negativo cujos fundamentos sejam o esvaziamento da linguagem, que se vê despojada de sua capacidade de dizer o mundo, e o aprendizado do não-saber.

Palavras-chaves: Linguagem apofática; Linguagem; Angelus Silesius; não-saber.

\begin{abstract}
Apophatic language is a genre closely related to negative theology, whose the most accomplished formulation is found in the Pseudo-Dionysius work (fifth century), who founded a mystical tradition that perpetuated throughout the Middle and Modern Ages. Several authors in contemporary such as Derrida (1995 and 1997), (Franke, 2007), (Pounde, 2003), (Vega, 2004 and 2009), and others, have highlighted the resumption of that genre in the Arts, Literature and the Humanities in general. Apophatic is, thus, a discourse that seeks transcendence, and it orients itself to denounce the emptiness intrinsic to language as well as to world, so that the God that there appears slips under our language without being caught in our discursive webs. In this text the impossibility of God's name becomes a metaphor to reflect, from the example of the mystique of Silesius Angelus, on the possibility of a negative thought whose foundations are the emptiness of the language, which finds itself stripped of its ability to tell the world, and from the learning of the notknowing.

Keywords: Apophatic language; Failure of language; Angelus Silesius; not-to knowing.

\footnotetext{
Artigo recebido em 14 de junho de 2010 e aprovado em 02 de setembro de 2010.

* O artigo integra minha tese de doutorado de título "Por um Deus que seja noite, abismo e deserto: considerações sobre a linguagem apofática", defendida em março de 2010 na PUC-Rio.

** Doutora em Estudos de Literatura (PUC-Rio, 2010). Professor substituta de Literatura Brasileira na UFRJ. País de origem: Brasil. E-mail: cleideoliva@yahoo.com.br
} 


\section{Introdução}

Uma das características mais marcantes do tempo contemporâneo é a declarada tríplice morte do sujeito, da linguagem e de Deus. Nessas circunstâncias, o discurso apofático tem se tornado praticamente uma koiné nas ciências humanas, uma língua comum para os discursos, mais ou menos catastróficos, sobre a circularidade da linguagem e a contingência do conhecimento e demais construtos humanos. Essa é, por exemplo, a opinião de William Franke (2007) em sua coletânea e análise de discursos apofáticos desde os clássicos até os tempos contemporâneos. Para ele, os discursos apofáticos se caracterizam principalmente por serem uma experiência de resistência da linguagem que nasce em momentos culturais em que há um colapso dos discursos de autoridade. A contemporaneidade seria, devido à absoluta crise de confiança no logos, uma época particularmente propícia ao surgimento desses discursos, que se caracterizariam por serem ataques à pretensão representativa da linguagem e tentativas de desestabilização das expectativas da linguagem como fundo literal/superfície figurativa. Para Frank, o indizível se mostra nos textos contemporâneos como os limites de uma opacidade intrínseca a todo discurso, uma inevitável não inteligibilidade no dizível. Dessa forma, "a experiência da apofática, como uma experiência daquilo que não pode ser dito, é essencialmente linguística: a experiência ela mesma é intrinsecamente uma experiência de fracasso da linguagem" (FRANKE, 2007, p. 3). ${ }^{1}$

Resta saber se essa confissão de fracasso não constituiria antes uma estratégia para se pensar o impensável, uma forma de escapar da dicotomia mythos versus logos, e assim desestabilizar a tirania do sentido e da referência, liberando o pensamento das armadilhas do antropocentrismo, que parece inerente a nossa cultura epistêmica.

Investindo nessa possibilidade, gostaria de explorar as potencialidades do discurso apofático enquanto tentativa de construção de inteligibilidade e ethos a partir de alguns poemas do místico alemão Angelus Silesius. O convite que faço é para pensarmos a mística apofática, e sua correlata teologia negativa, como um método que, por meio de rigorosa ascese da linguagem positiva e da razão discursiva, rejeita não apenas o sensível, mas

\footnotetext{
1 "The experience of apophasis, as an experience that of not being able to say is quintessentially linguistic: the experience itself is intrinsically an experience of the failure of language."
} 
também o inteligível, e propõe uma terceira via de acesso ao núcleo duro do real - que podemos também chamar de Deus - através da superação daquilo que Pondé (2003) chamou de angústia da referência semântica ou pragmática. Defende-se que o discurso da mística não se encontra no âmbito do non-sense, mas que o mesmo se constitui como uma tentativa de elaboração de um pensar que, nos instigantes versos de Fernando Pessoa, “exige um estudo profundo/uma aprendizagem do desaprender" (2005, p. 49) daquilo que milhares de anos de cultura e filosofia nos ensinaram.

A negatividade intrínseca a esse pensamento aproxima-o da chamada teologia negativa, ou apofática. Grosso modo, poder-se-ia definir a apofática como um método de kathársis (purificação) do discurso e da inteligência com fins de se alcançar aquilo que Pseudo-Dionísio ${ }^{2}$ chamou de Causa universal, ou treva superluminosa:

Como devemo-nos unir à Causa universal e transcendente, e como devemos louvá-la. Rezemos para encontrarmo-nos também nessa treva superluminosa, para ver através da cegueira e da ignorância, e para conhecer o princípio superior à visão e ao conhecimento. Louvaremos o princípio superexistente de maneira supernatural, removendo todas as coisas: do mesmo modo pelo qual aqueles que modelam uma bela estátua aplainam-lhe os impedimentos que poderiam obnubilar a pura visão de sua arcana beleza, sendo capazes de mostrá-la plenamente, mediante a remoção. A meu juízo, as negações e as afirmações devem ser louvadas com procedimentos contrários: com efeito, afirmamos, quando partimos dos princípios mais originários e descemos também dos membros intermédios às ultimas coisas; no caso das negações, todavia, removemos tudo, quando subimos das últimas coisas às mais originárias, para conhecer a ignorância escondida em todos os seres por todas as coisas cognoscíveis, e para ver a treva supernatural escondida por todas as luzes presentes nos seres. (PSEUDO-DIONÍSIO AEROPAGITA, 2005, p. 2122, grifo itálico nosso).

Esse trecho é significativo para compreender vários aspectos do discurso apofático: a afirmação de uma realidade/princípio que transcende nossas possibilidades cognitivas de

\footnotetext{
${ }^{2}$ Chamado assim porque, para emprestar maior autoridade a esses escritos surgidos no século V a.C, atribuiuse a autoria àquele Dionísio que o apóstolo Paulo converteu com seu discurso no Areópago. Dionísio legounos um corpus de escritos que abrangem a Hierarquia celeste, Hierarquia eclesiástica, Nomes divinos, Teologia mística e Epístolas. A partir das formulações de Proclo, Pseudo-Dionísio relê o platonismo a partir de óculos cristãos e propõe uma experiência de Deus por via extática que se relaciona com um "modo de conhecer" que é simultaneamente supraintelectivo e suprassensível. Sua obra influenciou grandemente toda a tradição da apofática cristã, e apenas como exemplo tomemos Dante e a estrutura hierárquica do Paraíso. (SAMYN, 2007).
} 
apreensão e, ao mesmo tempo, o postulado de que seja possível um modo de cognição/experiência desse princípio via união de substâncias humana e transcendente. E ainda, a menção da metáfora do escultor que "retira" da matéria a escultura desejada removendo os "excessos" que nos impedem de vê-la. Assim, o caminho que aqui se propõe para a contemplação mística incluiria a remoção de predicados que impedem a plena visão da deidade em toda sua beleza e incognoscibilidade, caminho que configura propriamente o método da teologia negativa. Note-se que, para Pseudo-Dionísio, as teologias afirmativa e negativa não competem entre si ou se excluem, antes, são complementares e correlativas: a primeira é de ordem descendente - na tentativa de nomear Deus, vai-se dos nomes mais altos e nobres até o mais inferior, nomeando-O como o Bem, o Ser, a Vida, a Beleza, o Saber, etc.; a segunda teologia é de ordem ascendente - vai-se da negação (remoção) dos Nomes mais simples e humildes até um além categorial, no Inefável onde brilham as trevas divinas (SANTOS, 2004, p. 36). Se a teologia catafática afirma de Deus que Ele é o Bem, o Ser, a Beleza, a Verdade, o Saber..., a teologia negativa irá negar cada um desses atributos, dizendo que Ele não é o Bem, o Ser, a Beleza, a Verdade, o Saber... Não se trata de uma contradição, alerta Santos, mas sim de um método de superação: "uma afirmação transhumana, pois seu objeto escapa a todas as categorias, a todas as nossas afirmações e a todas as nossas negações. A afirmação só valerá na medida em que for penetrada pela preferível negação, que orienta diretamente para o Inefável” (SANTOS, 2004, p. 36-37). Aí, nesse "lugar" inabitado, “A inteligência arrebatada constituirá o estado teopático em que o místico experimenta a Deus, produzindo assim uma simpatia com a realidade conhecida, obtendo de Deus, por conseguinte, não somente um saber, mas uma experiência vivida” (SANTOS, 2004, p. 40-41). Pelo método apofático, o que se conhece é "a ignorância escondida em todos os seres", e o Deus que se experimenta é "treva supernatural escondida por todas as luzes presentes nos seres".

A teologia apofática, essa ficção iconoclasta considerada por Derrida como a “experiência mais pensante, a mais exigente, a mais intratável da 'essência' da linguagem" (DERRIDA, 1995, p. 34), testemunha um núcleo irredutível e silencioso, um excesso, ou, em termos bataillianos, uma parte maldita, que retorna ad infinitum, falando silenciosamente sem comunicar "produtivamente" (BATAILLE, 1987, p. 56). Discurso que se erige sobre a sua própria ruína, a teologia apofática é coextensiva à teologia catafática 
(afirmativa), de tal forma que a negação não é privativa, e sim uma superafirmação de excelência: na via-crúcis para purificação dos conceitos humanos, o método apofático faz um movimento ascendente de negação dos predicados, dos mais simples aos mais nobres, orientando-se diretamente para o Inefável, mas negando qualquer possibilidade de aproximação conceitual de Deus. Nenhum nome é adequado à divindade superessencial, não obstante, é preciso atender a Seu chamado, e é irrecusável chamá-Lo, encontrar um Nome silencioso com o qual possamos adorá-Lo, pois, como bem notou Derrida, é a dupla via da oração e da adoração que marca a linha divisória, talvez opaca mas com certeza precisa, entre a teologia negativa e o niilismo. Há a promessa de uma presença que permeia a teologia negativa, uma Referência absoluta que não apenas legitima essa fala como também a torna possível, e é a essa presença que o místico dirige sua oração, celebração ou louvor, sendo essa experiência singular de oração/louvor que guia seu discurso para longe de toda negação vazia e puramente mecânica. ${ }^{3}$ Oração que não é um preâmbulo ou um modo acessório de acesso, mas um chamamento a esse completamente outro que convida ao deserto, como veremos na citação de Derrida:

Uma experiência deve guiar a apofática até a excelência, não deixar que diga qualquer coisa, evitar que manipule suas negações como discursos vazios e puramente mecânicos. Esta experiência é a oração. A oração não é aqui um preâmbulo, um modo acessório de acesso. Aquela constitui um momento especial, ajusta a ascese discursiva, a passagem pelo deserto do discurso, a aparente vacuidade referencial que não evitará o mal delírio e a tagarelice a não ser começando por dirigir-se ao outro, a ti. Porém a ti como "Trindade Superessencial e mais que divina". (DERRIDA, 1997, p.17). ${ }^{4}$

\footnotetext{
${ }^{3}$ Aqui está, a nosso ver, o principal argumento de Derrida àqueles que o "acusam" ou o "parabenizam" por estar recuperando o método da teologia negativa com a sua desconstrução. Sobre o assunto ele afirma: "No lo que escribo no depende de la "teología negativa". En primer lugar en la medida en que esta pertenece al espacio predicativo o judiciativo del discurso, a su forma estrictamente preposicional, y privilegia no solo a unidad indestructible de la palabra sino también la autoridad del nombre, axiomas todos ellos que una "desconstrución" debe empezar por reconsiderar (cosa que he intentado hacer desde la primera parte de De la gramatología). Después, en la medida en que aquella parece reservar, más allá de toda predicación positiva, más allá de toda negación, más allá incluso del ser, alguna especie de superesencialidad, un ser más allá del ser. (DERRIDA, 1997, p. 03)

${ }^{4}$ Una experiencia debe guiar todavía la apófasis hacia la excelencia, no dejarle que diga cualquier cosa, evitar que manipule sus negaciones como discursos vacíos y puramente mecánicos. Esta experiencia es la de la oración. La oración no es aquí un preámbulo, un modo accesorio del acceso. Aquella constituye un momento especial, ajusta la ascesis discursiva, el paso por el desierto del discurso, la aparente vacuidad referencial que no evitará el mal delirio y la palabrería a no ser comenzando por dirigirse al otro, a ti. Pero a ti como "Trindad Superesencial y más que divina". (Tradução nossa).
} 
Assim, na leitura de Derrida, a negação e recusa do nome é, ao contrário do que parece, salvar o nome e "constatar a transcendência referencial da linguagem":

Responder ao verdadeiro nome de Deus, ao nome ao qual Deus responde e corresponde além do nome sob o qual nós lhe conhecemos ou lhe ouvimos. É com esse fim que o procedimento negativo recusa, nega, rejeita todas as atribuições inadequadas. Ela o faz em nome de uma via de verdade e para ouvir o nome de uma voz justa. (DERRIDA, 1995, p. 55).

Para Derrida, a teologia negativa, esse projeto de falência da linguagem - essa parece ser a melhor definição de teologia negativa - seria uma espécie de estratégia cognitiva para se "salvar o Nome" de quaisquer ameaças especulativas e/ou céticas. Derrida parece minimizar o caráter iconoclasta da teologia apofática, ao contrário de scholars como Paulo Borges, para quem a via apofática, na medida em que busca uma experiência transconceitual da realidade última, não é ortodoxa ou conservadora, e sim um exercício de pensamento extremamente radical em sua proposta de emancipar o humano de todas as balizas conceituais e representações que dão sentido e estabilidade cognitiva a seu mundo. A citação abaixo, apesar de longa, sintetiza esse posicionamento de Borges:

Poder-se-ia dizer que a verdade última da religião, desvelada pela mística, é a morte de Deus, vivida não só como a extinção de todos os conceitos e representações religiosos e teológicos, mas também como a ausência, a abs-entia, a não entidade, a vacuidade, da suposta Presença absoluta (a qual, noutro sentido, pode também ser vista como a ressurreição de Deus da morte infligida à sua Vida pelos mesmos conceitos e representações religiosos e teológicos). Assim sendo, e para dialogar apenas com uma das emergências do tema da "morte de Deus" no pensamento ocidental, cremos ser esta principal morte de Deus, inerente à experiência última do que se designa como Deus, que permite compreender o efeito da morte de Deus proclamada pelo "louco" nietzcheano: "Para onde vamos nós próprios? [ ...] Não estaremos incessantemente a cair? Para diante, para trás, para o lado, para todos os lados? Haverá ainda um acima, um abaixo? Não estaremos errando através de um vazio infinito? Não sentiremos na face o sopro do vazio?". Não será afinal, essa experiência de vazio, ausência de fundo e referências - consequências da humana abdicação da ideia de um absoluto princípio ordenador do mundo e da vida - a própria experiência desse abismo, fundo sem fundo, deserto e morada onde ninguém mora que a tradição mística vive como a experiência última de transcender a Deus?”(BORGES, 2009, p. 6). 
Discurso que visa à própria transcendência, a mística apofática é uma fala que se orienta para a denúncia de um vazio intrínseco à linguagem (representativa) e ao mundo que dela se origina. Investindo contra as formas de cognição via representação, o discurso apofático se orienta para o esvaziamento das possibilidades previstas de cognição, e se caracteriza por ser "um modo de contemplar o nome (a 'alteridade' de Deus) que altera o fazer ontológico (e com esse todas as formas desdobradas de conhecimento)" (PONDÉ, 2003, p. 89).

\section{Transcendência (do mundo, de si e de Deus) e não-saber}

Angelus Silesius nasceu na Polônia, em 1624, dentro de uma tradicional família luterana, tendo como nome de batismo Johannes Scheffer. O pseudônimo veio depois, com a conversão ao catolicismo (em 1653, aos 28 anos), e faz referência a Silésia, sua terra natal, onde nasceu outro grande místico, Jacob Böhme.

Tendo estudado medicina e filosofia em instituições respeitadas em Leyden (Holanda) e Pádua (Itália), em 1649 Scheffer é nomeado médico particular do príncipe de Öls, frequentando círculos místicos e ligando-se a Abraham Von Franckenberg, que possui forte sensibilidade religiosa de viés ecumênico, além de reunir em torno de si um círculo de eruditos, alquimistas, intelectuais e místicos cujos interesses iam da alquimia à literatura, da mística à medicina, da biologia à metafísica. A influência de Abraham Von Franckenberg é intensa, apesar do pouco tempo de convivência - Von Franckenberg morrerá em fins de 1652 -, e esse desempenhará o papel de mestre socrático na iniciação de Scheffer no itinerário místico. Após a morte do amigo e mentor, Scheffer herda sua biblioteca, pródiga em obras de místicos como S. Boaventura, Ruysbroeck, Tauler, Suso, Tomás de Aquino e Jacob Böhme, esse último amigo íntimo de Von Franckenberg. Scheffer se demite do cargo

de médico pessoal do príncipe de Öls e retorna para Breslau, mergulhando nessas leituras místicas.

Em 1653, em circunstâncias não muito claras, Scheffer se converte ao catolicismo, tomando o sacramento da crisma e adotando o pseudônimo de Angelus Silesius (mensageiro da Silésia). A conversão de Silesius acontece juntamente com a escrita dos livros III, IV e $\mathrm{V}$ do livro Viajante querubínico, podendo-se notar na obra um 
endurecimento doutrinário e um declínio da poesia. Em 1661, ele recebe a ordenação sacerdotal, tornando-se um ardoroso combatente do protestantismo, e se dedica a escrever livros panfletários, de teor apocalíptico e qualidade literária duvidosa, contra os "pecadores e hereges" protestantes.

O Viajante querubínico (Kerubimnischer Wandersmann), com o subtítulo "Epigramas e máximas espirituais para levar à contemplação de Deus", é organizado em epigramas com dísticos rimados em metro alexandrino, forma poética inflexível e áspera que parece adequar-se ao poema aforístico e sentencioso. Na análise de Franke, o aforismo alexandrino é uma forma poética minimalista, que diz o mínimo para sugerir o Todo, trazendo para dentro da linguagem a gagueira e o silêncio advindos da experiência do inarticulado, principalmente através do recurso da cesura, própria dos versos alexandrinos. ${ }^{5}$ Em uma das traduções portuguesas que usaremos para a maioria dos poemas, o rigor estilístico do original alemão não é adotado por Dora Ferreira da Silva, a poeta responsável pela tradução. Em palavras da própria Dora, a tradução portuguesa tenta "sugerir a estreiteza da forma em contraste com a carga explosiva do conteúdo", havendo "(...) uma opção pela 'pobreza' da forma (corpo) veiculando a superabundância de uma experiência mística que se processa no abismo da alma, numa espécie de quenose poética" (LEPARGNEUR; SILVA, 1986, p. 67).

Pertencendo à mesma tradição apofática de Meister Eckhart, as imagens desérticas comparecem nos poemas de Silesius como figuras de uma necessária aporia: a necessidade de ir além de Deus, ultrapassando toda forma de relação objetal entre um eu humano e um Tu divino. Veja-se o conjunto de epigramas abaixo, em cujo título já fica claro esse imperativo de transcendência humano-divina:

\section{Devemos ir para além de Deus}

Onde é minha morada? Nem eu, nem tu lá estamos. Qual é o fim encontrado? Onde nada encontramos. Como prosseguir e o que fazer por certo? Ultrapassando Deus*, entrar pelo Deserto. (I, 7).

Ou seja, para além de tudo que se conhece de Deus e que dele se pode pensar, conforme a contemplação negativa, sobre a qual vejam-se os místicos. (LEPARGNEUR; SILVA, 1986, p. 5)

\footnotetext{
${ }^{5} \mathrm{O}$ processo de cesura significa a quebra entre o primeiro e o segundo hemístico (que é o conjunto de seis sílabas poéticas) de um verso.
} 
Note-se que o aforismo propõe três perguntas, respondendo progressivamente a cada uma delas. A primeira questão é sobre essa morada que é imperativo encontrar: a pergunta "Onde é minha morada?" tem como resposta a constatação de que esse é um lugar onde nem o eu nem o tu lá se encontram, ou seja, essa morada é um "lugar" que prescinde de toda relação objetiva e subjetiva, quer em se tratando de relações intra ou inter-humanas quer em se tratando da relação humano-divino. Paulo Borges chama atenção para a presença do verbo steben (estar) no verso "Nem eu, nem tu lá estamos", notando o que há de inpermanência desse eu e desse tu, que não podem ser lidos, na interpretação do autor português, como entidades fixas e estáticas em uma morada determinada, desde que essa morada aparece como um acontecer que rejeita toda entificação, sendo ausente de "objetos" com os quais um "sujeito" se ponha em relação. (BORGES, 2009, p. 7).

Novamente aqui a ideia de ultrapassar Deus, esquecê-Lo, abandoná-Lo na medida em que Ele seja objeto de conhecimento, compartilhando a máxima de Meister Eckhart de que seja preciso pedir a Deus que nos livre de Deus. ${ }^{6}$ Ir além de Deus é abandonar toda possibilidade de relação eu/Tu e toda pretensão cognitiva, pois essa morada que já se possui e à qual se deseja retornar é tanto um não lugar onde "nem eu, nem tu lá estamos" quanto uma espacialidade vazia “onde nada encontramos". É preciso, portanto, voltar a ser o que se é. Na análise precisa de Paulo Borges (2009), trata-se aqui do mesmo tema presente na mística de Eckhart e de outros místicos apofáticos: uma experiência transconceitual da realidade última que opera um retorno ao incriado - ao abismo eterno do ser divino - onde sujeito e divindade não mais "existem" enquanto determinações distintas entre si, em uma dupla abolição de todo referente possível: o sujeito da razão e o Deus/linguagem/sentido.

A segunda questão - Qual é o fim encontrado? - diz respeito ao fim que se encontra, ao encontrar tal morada. A resposta inquietante - Onde nada encontramos - situa definitivamente essa fala no gênero apofático. Contrariando a compreensão mecanicista de que todo movimento (humano e não humano) seja orientado por um sentido e uma teleologia, o poema nos fala de um Nada que se dispõe como horizonte tanto de partida quando de chegada para esse 'movimento' que, não obstante, é essencial ao místico. É preciso um percurso místico, um caminhar - o perambular da alma pela noite escura, em

\footnotetext{
${ }^{6}$ Tema tratado no sermão 52, de título “Bem-aventurados os pobres...” (ECKHART, 2004, p. 36)
} 
San Juan; a "saída" da alma para que Deus "entre" e o fundo da alma seja um com a deidade abissal em Eckhart $^{7}$ - que seja desapropriante, de tal forma que, ao fim, o fim que se encontra seja um nada encontrar, posto que toda determinação foi abandonada, não apenas as humanas (no sentido de uma ascese das paixões, dos saberes e da linguagem que é tratada exemplarmente no místico ibérico San Juan de la Cruz), mas também divinas (na medida em que seja preciso "perder" Deus para depois encontrá-Lo, como aparece no poema eckhartiano) em um processo que Borges chama de transcender o transcendente.

O ultimo dístico propõe novas questões, desta vez relacionadas ao "método" desse percurso e desse habitar que se desejou nos primeiros versos. "Como prosseguir e o que fazer" quando todas as balizas socioculturais e estabilidades cognitivas foram despedaçadas contra esse abismo sem fundo? A resposta é uma aparente aporia: “Ultrapassando Deus, entrar pelo Deserto". Aporia pois, afinal, como ultrapassar Aquele que é limite e borda de todo cognoscível? Sendo Deus o fundamento de todo fundado, como seria possível dEle abdicar? A dissolução dessa falsa aporia está na distinção echkartiana entre Gott e Gottheit, sendo o primeiro o Deus percebido, entificado, e tornado "objeto" de fé, dogma e teologia, e o segundo a Deidade anterior ao processo de distinção entre as pessoas da Trindade e de criação do mundo e do humano. Transdivina divindade abissal, Gotheit é um transcender de Gott, é esse deserto de permanência difícil ao qual é preciso retornar, 'recuperando' uma identidade íntima e indissolúvel entre homem e Deidade. Borges relaciona o deserto à metáfora eckhartiana da "centelha" ou "fundo da alma", a esse fundo incriado que é comparado pelo Meister com uma terra estranha, desconhecida e inominada que nos habita, apesar de não nos pertencer. ${ }^{8}$ Habitando o que nos é mais íntimo e transcendendo a toda entificação, a centelha/fundo da alma se encontra "no que é menos doméstico e habitável,

\footnotetext{
${ }^{7}$ Referência ao Poema Granum Sinapsis, de Meister Eckhart.

${ }^{8}$ Veja-se o trecho do sermão 28 de Meister Eckhart: “[Mas] en todo lo creado no hay - como ya dije varias veces - ninguna verdad. Hay una cosa que se halla por encima del ser creado del alma [y] a la que no toca ninguna criaturidad que es [una] nada; no la posee ni siquiera el ángel que tiene un ser puro que es acendrado y extenso; hasta él no la toca. Ella es afín a la índole divina, es una sola en sí misma, no tiene nada en común con nada. En cuanto a esta cosa muchos frailes insignes comienzan a cojear. Ella es una tierra extraña y un desierto, y antes que tener un nombre es innominada, y antes que ser conocida es desconocida. Si tú pudieras aniquilarte por un solo instante, digo yo - aunque fuera por un tiempo más breve que un instante - , te pertenecería todo aquello que [esta cosa] es en sí misma. Mientras todavía prestas alguna atención a ti mismo o a una cosa cualquiera, sabes tan poco de lo que es Dios, como sabe mi boca de lo que es el color, y como sabe mi vista de lo que es el gusto: tan poco sabes y conoces tú lo que es Dios". (MAESTRO ECKHART, 2007).
} 
onde nada nem ninguém na verdade habita, pelo menos como algo ou alguém” (BORGES, 2009, p. 8).

O desconhecimento como algo que seja próprio a Deus é tratado em outros poemas de Angelus Silesius. Veja-se este, cujo título - O Deus desconhecido - de início faz referência à tradição apofática iniciada pelo Pseudo-Dionísio, mais especificamente ao episódio da pregação de Paulo em Atenas, quando o apóstolo, diante de um altar intitulado “Ao deus desconhecido", faz uma pregação à qual se converte o grego Dionísio, confundido posteriormente com o autor desse corpus místico que influenciou toda a tradição da apofática cristã.

\author{
O Deus desconhecido \\ O que é Deus, não o sabemos. Ele não é luz, não é espírito. \\ Não é verdade, nem unidade, nem um, ele não é aquilo \\ que chamamos divindade. \\ Não é sabedoria, não é intelecto, não é amor nem querer nem bondade. \\ Nem uma coisa, muito menos uma não coisa, \\ Não é uma essência, não é um coração. \\ Ele é aquilo que nem eu, nem tu, nem nenhuma criatura, \\ antes de ter-se tornado aquilo que ele é, jamais conhecemos. (IV, 21).
}

O poema se inicia com uma embaraçosa confissão, caso se tratasse de um texto confessional ou litúrgico: o que Deus é, não o sabemos. Essa assunção de uma ignorância não ultrapassável lembra-nos o método maiêutico de Sócrates, que produz resultados cognitivos negativos dado que visa uma coreografia epistêmica entre as cavernas dos conceitos e a noite escura do inarticulado. Assim também parece proceder o pequeno aforismo de Silesius. A afirmação inicial de que não sabemos o que Deus é prossegue com uma série de negativas que $\mathrm{O}$ vão afastando progressivamente daquelas imagens mais tradicionais da divindade. É importante notar que a declaração seja a de que não saibamos o que Deus é, e não quem Deus é, já de início demarcando um estranhamento ontológico: não se trata aqui de uma pessoa ou de um sujeito, ainda que com prerrogativas divinas. Trata-se de um algo ou alguma coisa sobre a qual nosso discurso só pode se pronunciar negando-se. E as negações se acumulam, alcançando definições clássicas da ontologia divina: não sendo luz, nem espírito, nem verdade, nem unidade, nem divindade, nem sabedoria, nem intelecto, nem amor, nem bondade, nem uma coisa, nem uma não coisa, nem essência, nem um coração, o que poderia Deus ser? Aliás, seria pertinente usar tal categoria - do Ser - 
para se falar desse Isso que desliza sobre nossa linguagem sem ser apreendido por ela? Como notado por Derrida, "Deus 'é' o nome desse desmoronamento sem fundo, dessa desertificação sem fim da linguagem" (DERRIDA, 1995, p. 37). É um nome que não nomeia nem afirma nada, ainda que, em se perdendo esse Nome, salvo o nome, por ele seja salvo todo nome, ou mesmo a própria possibilidade de nomeação.

Ao fim das negativas, o poema termina com uma declaração que causa maior embaraço ainda: em sendo algo que rejeita todos nossos óculos epistêmicos, a única forma de conhecer o que seja Deus é tornar-se também Deus, naquele processo de deificação que já mencionamos anteriormente quando comentávamos a mística eckhartiana, e que é tão central em Angelus Silesius. O conhecimento que aqui se exige é conhecimento por participação, sendo preciso tornar-se um com o Um para então conhecê-Lo, prescindindo das relações sujeito-objeto, interior-exterior, superfície-profundidade, essência-existência, etc. Conforme nosso entendimento, um tal tipo de conhecimento pode ser denominado de pensamento ecológico, na medida em que rejeita determinados pressupostos e conclusões do paradigma mecanicista e propõe um modo de aproximação "entre coisas" que não seja hierarquizado e/ou regulado por pretensões de superioridade, bem como por essas ficções tão úteis que são as noções de sujeito, objeto, objetividade, isenção, reprodutibilidade da experiência, estabilidades conceituais...

Ainda segundo Derrida, o método negativo propõe a experiência de Deus como espacialidade vazia e desértica, espaço "puro" e isento de toda humanização de onde a palavra (o verbo) é pronunciada em um tempo imemorial, em uma eternidade que é "agora" e "sempre", em permanente devir, de modo que a palavra esteja sempre em vias de se tornar carne, mas sempre impronunciada. Veja-se o belo aforismo abaixo, no qual Derrida se apoia para tais considerações:

\section{O lugar é a Palavra}

Um são o lugar e o Verbo, e se o lugar não existisse

(Pela eterna eternidade) também o Verbo não seria. (I, 205).

Para se chegar a esse "lugar", faz-se necessário, em consonância com os demais místicos que estivemos analisando, um itinerário no qual os passos vão sem saber para onde, os olhos veem sem saber o quê, e os ouvidos ouvem o som inexistente, 


\section{Deus fora da criatura}

Caminha onde não podes! Olha onde não vês!

Ouve onde nada ressoa: estarás onde Deus fala. (I, 199).

É apenas aí, quando o impossível é experienciado enquanto impossibilidade de sensibilidade e cognição, que o homem místico pode estar nessa espacialidade indemarcável - no deserto - e ali ouvir o pronunciar do verbo primordial. Um filosofema também importante na mística de Silesius é o de empobrecimento que culmina em uma aniquilação deificante. O tema da pobreza/nobreza de espírito é aqui retomado em termos muito próximos aos de Eckhart e San Juan de la Cruz, como se vê nos epigramas abaixo:

\section{A impotência que pode}

Quem nada deseja, nada tem, nada sabe, nada ama nem quer, Sempre muito mais tem, sabe, deseja e ama. (I, 45).

E também:

\section{A nudez repousa em Deus}

Feliz o espírito no seio do Amado!

Despido de si, de Deus, do mundo criado. (I, 130).

Os paradoxos, tão a gosto dos místicos em análise, são abundantes nesse pequeno aforismo. Mais uma vez, o percurso místico fará exigência pelo abandono de toda potência humana, não apenas de ato, mas também de desejo, pulsão. É necessário tornar-se fraco pois, como ensina o apóstolo Paulo, é quando estou fraco que sou forte, ${ }^{9}$ tendo, sabendo, desejando e amando em plena liberdade e desprendimento muito mais do que quando isso que se tem, sabe, deseja e ama é parte de meu ser. É preciso, portanto, tudo abandonar: gelassenheit, deixar ser, deixar-se, desprender-se, liberar, liberar-se, palavra do vocabulário eckhartiano que fica implícita nesse aforismo e que aparece claramente em outros como: "O desapego (gelassenheit) captura Deus: mas renunciar até mesmo a Deus/ é um modo de desapego (gelassenheit) que poucos homens compreendem" (II, 92). Os imperativos continuam, e já são nossos conhecidos: exige-se uma nudez absoluta, pura e radical para se ter acesso ao terno repouso nos braços do Amado, metáfora amorosa que retorna e restabelece, na poética de Angelus Silesius, os mesmos topoi do encontro amoroso divino-

\footnotetext{
${ }^{9}$ Segunda Carta aos Coríntios, 12, 10 (A BíBLIA DE JERUSALÉM, 1985).
} 
humano tão caros às beguinas, a San Juan de la Cruz e a outros místicos ibéricos. Despir-se de si mesmo, da própria subjetividade, dos desejos, das pulsões, das heranças culturais, dos pressupostos e conceitos. Despir-se do mundo criado, da beleza, da dor, do sofrimento, do medo, das paixões que ele desperta. Despir-se por fim do próprio Deus, das ideias e dos enganos que porventura nosso desejo de presença possa ter provocado: abandoná-Lo, deixá-Lo ir, estar só, nu, fraco e repousado frente a esse Isso que apenas chamamos Deus pela necessidade irrecusável de ainda chamá-Lo.

Aniquilar-se. Tornar-se nada, eis aí o (quase) fim da experiência e desse percurso místico, exceto pelo fato de que o fim é ponto de origem, sendo esse caminhar um retorno àquele momento primeiro em que o pré-sujeito estava plenamente repousado na Deidade pura e sem distinções, em um gozo eterno imemorial: "Um puro Nada, sem presente ou passado: a beatitude do homem deificado!"(II, 92), e também "A doce divindade é nada e menos que nada: / quem nada vê em tudo, acredita, homem, vê bem!’” (I, 111). O Nada que aqui se convoca não deve ser compreendido em termos essencialistas, sendo, portanto, inconfundível com o não Ser, remetendo antes para a noção de ausência não privativa ou negativa, e referindo-se ao incriado e não nascido. Paulo Borges traz à memória o substantivo feminino nonada: não nada, mas também bagatela, insignificância, ninharia, e põe em destaque o fato de que o que vocábulo afirma não é a negação do ser ou do ente, e sim a ausência de determinação ontológica, e mesmo de transcendência da mesma.

O nada indica o que está antes e além do ser, conforme a sua procedência, nas duas línguas ibéricas, da expressão latina nulla res nata, ou seja, a instância anterior à manifestação ou, mais explicitamente, o non natum, o não nascido, o não manifestado, o não determinado, o incondicionado e incriado: na verdade, apesar destas expressões ainda negativas, próprias dos limites onto-lógicos do conceito e da linguagem, aquilo que não está condicionado por "ser" ou "ser algo" nem pela sua negação. O nada indica aquilo que transcende o domínio onde se constituem e operam dialecticamente os conceitos dualistas de ser e não ser, indicando o que transcende todas as possibilidades da predicação lógica: ser, não ser, ser e não ser, nem ser nem não ser; $\mathrm{A}$, não $\mathrm{A}, \mathrm{A}$ e não $\mathrm{A}$, nem $\mathrm{A}$ nem não $\mathrm{A}$ (BORGES, 2006, p. 9). 
Transcendência que exige prévia aniquilação:

\section{A aniquilação de si mesmo}

Nada te eleva mais acima de ti mesmo que a aniquilação:

Quem é mais aniquilado tem em si mais divindade. (II, 140).

No aforismo acima, Silesius faz menção a uma gradação desse aniquilamento que se propõe a alma mística e, nesse caso, menos é mais: quanto menos se é em si mesmo, mais se possui da centelha divina. A aniquilação suprema, objetivo final do místico que é preciso entender enquanto idealidade a conduzir uma práxis que, exceto em raros casos, nunca se esgota, ${ }^{10}$ é sinônimo de plena deificação, confusão de substâncias que leva Silesius a exclamar, à beira do escândalo dos fracos: "Sou criança e filho de Deus. Ele é meu filho: / então como podemos ambos, ser os dois?’(II, 250). Pergunta difícil essa, à qual nos recusamos seguindo conselho do próprio Silesius, que afirma em outro dístico:

\section{Tu mesmo deves sê-lo}

Não perguntes o que é divino! Pois se não o és,

Mesmo que disso te falem, meu cristão, não o saberás. (II, 142).

A questão que aqui comparece é a declaração de impossibilidade para o saber sobre Deus, declaração paradoxalmente vinculada ao postulado de que seja possível experienciar, no próprio corpo, o que Deus é por meio de um processo místico que conjuga desprendimento (abegescheidenheit) e abandono (gelassenheit) - de si, do mundo e do próprio Deus-percebido-e-relacional -, aniquilação e deificação. Entendendo Deus como um "claro relâmpago e também escuro nada,/ que nenhuma criatura vê com sua própria luz (II, 146)", Silesius nos dá uma poderosa pista para compreender esse discurso (apofático) que se erige sobre sua própria ruína, teimando em falar daquilo que não pode ser dito. Na mesma medida estranha e inquietante que é claro relâmpago, bela imagem desse corte que rasga o corpo da linguagem e imprime no mundo as marcas de nosso desejo e necessidade de inteligir, Deus também é "escuro nada", noite escura que confunde, atordoa, embaraça os sentidos e rouba a capacidade de movimento e ação nesse mesmo mundo. Um Deus que

\footnotetext{
${ }^{10}$ Estamos pensando aqui em alguns místicos que levaram às últimas consequências essa autoaniquilação, como a beguina Marguerite Porete, queimada viva pela Inquisição em 1310 em função de seus escritos considerados heréticos pela Igreja de então.
} 
é noite, abismo e deserto ${ }^{11}$ pouco se presta a servir de fundamento para nossas pretensões megalomaníacas de saber/poder que menosprezam o fato de que, para além do poder, saber também é gozo, ${ }^{12}$ tantas vezes inútil e dispendioso.

\section{Considerações finais}

Alimentando nosso desejo de impossíveis, a literatura apofática se oferece como uma poderosa linguagem que teria o poder de dizer "o ser do mundo" justamente porque se recusa a dizê-lo, porque se obstina em negar esse mesmo Nome ao qual não se cansa de chamar. Discurso destinado ao exílio e ao deserto, confessa Derrida. Entretanto, apesar da aparente contradição, a mística apofática nos oferece um modelo de pensamento que se mostra bastante produtivo para um mundo despovoado de deuses, pois esse é um pensamento que não se imobiliza em doutrinas e dogmas, mas que, reconhecendo a impossibilidade do conhecimento - o único conhecimento possível é a negação do conhecer - ainda assim demanda uma práxis compartilhada (a oração, o louvor).

Assim, o que a mística apofática parece nos mostrar é que, quando perguntamos pelo nome de Deus - nome facilmente substituível pelos termos linguagem, real, sentido... -, a única coisa que poderemos encontrar é o próprio nome que chamamos, o que teremos é ainda o que já tínhamos: apenas uma espacialidade vazia, um deserto inabitado ou um abismo sem fundo restará como princípio e fundamento a nosso chamado. O que subsiste é só o Nome, ao qual chamamos por força de nossa fé compartilhada em um ethos e uma práxis humana.

\section{Referências}

A BIBLIA DE JERUSALÉM. São Paulo: Edições Paulinas, 1985.

BATAILLE, George. O erotismo. Porto Alegre: L\&PM Editores, 1987.

\footnotetext{
${ }^{11}$ Essas são metáforas bastante comuns na mística apofática, e foram exploradas pelo autor em sua tese de doutorado já citada.

${ }^{12}$ Lembremos que a palavra saber veio do latim vulgar sapere - ter sabor, bom paladar, sentir os cheiros migrando depois para sabidus, sábio, aquele que percebe o mundo de modo organizado, usando os sentidos e a intuição. Conforme notações etimológicas de Deonísio da Silva (2009).
} 
BORGES, Paulo. Do bem de nada ser. Supra-existência, aniquilamento e deificação em Margarida Porete. Metabasis, septembre 2006, ano I, nº 2, p. 09.

BORGES, Paulo. Transcender Deus: de Eckhart a Silesius. Revista Philosophica do Departamento de Letras da Universidade de Lisboa. Anselmo sola ratione 900 anos depois. Lisboa: Edições Colibri, 2009.

DERRIDA, Jaques. Como no hablar: denegaciones. Cómo no hablar y otros textos. Traducción de Patricio Peñalver. Proyecto A, 1997, pp. 13-58. Edición digital de Derrida en castellano.

DERRIDA, Jaques. Salvo o nome. Campinas: Papirus Editora, 1995.

ECKHART, Mestre. Sobre o desprendimento e outros textos/ Mestre Eckhart. Rio de Janeiro: Martins Fontes, 2004.

FRANKE, William. Edited with theoretical on critical essays. On what cannot be said. Vol. I. Formulation's classics. University Notre Dame Press, 2007.

LEPARGNEUR, Hupert; SILVA, Dora Ferreira da. Angelus Silesius. A mediação do nada. São Paulo: T.A. Queiroz, 1986.

MAESTRO ECKHART, 2007) . Tratados y sermones. Recopilación y Traducción de Ilse M. de Brugger. Edición original - Buenos Aires 1977; Edición Electrónica - Buenos Aires 2007. Accesible por:

http://www.laeditorialvirtual.com.ar/Pages/MeisterEckart/00_Indice.htm. Acessado em fevereiro de 2008.

PESSOA, Fernando. Poesia completa de Alberto Caieiro. São Paulo: Companhia das Letras, 2005.

PSEUDO-DIONÍSIO AREOPAGITA. Teologia Mística. Tradução Marcus Lucchesi. Rio de Janeiro: Fissus, 2005.

PONDE, Luiz Felipe. Elementos para uma teoria da consciência apofática. Revista de Estudos da Religião. No 1, 2003, pp. 74-92.

SAMYN, Henrique Marques. O símbolo contra o texto: Pseudo-Dionísio Aeropagita e a irrepresentabilidade divina. Revista Mirabilia, no 7, dez, 2007, pp.29-38. Acessível por: http://www.revistamirabilia.com/Numeros/Num7/numero7_2.html, acessado em 07.10.2009.

SANTOS, Bento Silva. Introdução. PSEUDO-DIONÍSIO AEREOPAGITA. Dos nomes divinos. Introdução, tradução e notas de Bento Silva Santos. São Paulo: Attar, 2004.

SILESIUS, Angelus. O peregrino querubínico. Tradução Ivo Storniolo. São Paulo, Paulus, 1996. 
SILVA, Deonísio da. Etimologias. Acessível por:

http://www.caras.com.br/edicoes/806/textos/10741/, acessado em 25.01.2009

VEGA, Amador. Estética apofática y hermenéutica del misterio: elementos para una critica de la visibilidad. Dianóia, vol. LIV, no 62 (mayo 2009), pp. 3-25.

VEGA, Amador. Experiencia mistica y experiencia estetica en la modernidad. La experiencia mistica: estudio interdisciplinar. Madri: Editorial Trotta, 2004. 